\title{
ANALISIS PERBEDAAN GENRE GAME PADA GOOGLE PLAY MENGGUNAKAN FRAMEWORK OCTALYSIS
}

\author{
Dema Mathias Lumban Tobing ${ }^{1}$, Ema Utami ${ }^{2}$, Hanif Al Fatta ${ }^{3}$ \\ 1,2,3) Magister Teknik Informatika Universitas AMIKOM Yogyakarta \\ Jalan Ringroad Utara, Condong Catur Sleman Yogyakarta \\ Email: dema.16@students.amikom.ac.id, emma@nrar.net, hanif.a@amikom.ac.id
}

\section{ABSTRACT}

Android-based games are divided into various genres so that there are many variations of the game that can be played but many game developers don't know how to develop games based on the player's perspective that is closely related to human computer interAction.

The purpose of this study was to find out the strongest characteristics of player motivation in each genre available on Google Play using Octalysis framework based on design and gameplay so that differences in player motivation were found. The Octalysis Framework has been used by many companies to make gamification products, because in gamification there are game elements so that they can be used to analyze game products.

With this research, it is expected that each genre has the strength of characteristics and weaknesses as a benchmark of data for developers and game designers to create more varied games.

KeyWord : Framework, Octalysis, Game, Human Computer Interaction, Google Play, Android

\section{PENDAHULUAN}

Perkembangan teknologi yang masif mempengaruhi perkembangan di berbagai bidang hiburan salah satunya adalah game. Memasuki era teknologi portabel, game dapat dimainkan di berbagai perangkat termasuk menggunakan perangkat keras smartphone. Menurut data Statista pada tahun 2017 sistem operasi yang menguasai pasar hingga $85,9 \%$ adalah Android (Statista, 2017). Dengan jumlah pengguna Android yang sangat besar maka peluang terbesar bagi pengembang game adalah membuat game berbasis Android. Google Play menyediakan 17 genre namun tidak semua genre game memiliki popularitas yang sama sehingga pengembangan game dilakukan terus pada genre yang paling popular. Kepopuleran sebuah genre game dipengaruhi oleh jumlah pengunduh yang besar karena pada genre yang dimainkan tersebut dapat mempengaruhi motivasi pemain. Motivasi pemain merupakan bagian dari bidang ilmu human computer interaction karena di dalam sebuah game sangat dipengaruhi oleh desain dan gameplay yang terdapat di dalamnya. 
Penelitian mengenai Human Computer Interaction ( $\mathrm{HCl}$ ) di bidang game dilakukan untuk menganalisa setiap genre game pada Google Play dengan mengukur elemen terkuat di dalam sebuah genre. Analisis dilakukan karena perusahaan pengembang game memiliki kecenderungan menciptakan game dengan desain yang sama sehingga ditemukan setiap genre memiliki karakteristik yang sama berdasarkan elemen desain. Analisis untuk menemukan elemen terkuat pada genre game dilakukan menggunakan parameter Tracy Fullerton (Satria, Utami, \& Luthfi, 2018).

Analisis pada ilmu human computer interaction di bidang game dikembangkan dengan menganalisa motivasi pemain berdasarkan game rules terhadap game Candy Crush Saga yang memiliki popularitas tinggi dan bertahan hingga 10 tahun terakhir menurut data Statista dan Farmville game yang popularitasnya hanya bertahan selama 4 tahun menggunakan framework Octalysis. Framework Octalysis yang digunakan untuk mengetahui karateristik motivasi pemain dalam sebuah game. Hasil analisis dari kedua game tersebut ditemukan bahwa Candy Crush Saga memiliki nilai dan keseimbangan Octalysis yang seimbang sedangkan Farmville memiliki nilai Octalysis terendahnya yaitu unsur Unpredictability di mana game tersebut terlalu mudah diprediksi oleh pemain apa langkah selanjutnya dalam permainan ini (Yu-Kai, 2016).

Framework Octalysis dilakukan pengujian pada review game dengan membandingkan review menggunakan Metacritics. Obyek game yang digunakan di dalam pengujian ini adalah game Half Life dan Deus Ex: Fall Out. Hasil dari pengujian ini ditemukan bahwa review menggunakan framework Octalysis dan Metacritics memiliki persamaan mengacu pada motivasi pemain namun perbedaan yang ditemukan bahwa Metacritics memiliki nilai subyektifitas yang lebih tinggi berdasarkan perasaan manusia dibandingkan dengan framework Octalysis yang mengacu berdasarkan gameplay (Salonen \& Mohammad, 2017).

Pada penelitian ini akan dilakukan dengan mengembangkan unsur motivasi pemain yang telah ditemukan dengan menambahkan variabel secara kuantitatif di mana penilaian menggunakan skala Likert dan 
dilakukan pengujian terhadap genre game yang tersedia di Google Play yang bertujuan untuk menemukan unsur motivasi pemain berdasarkan unsur desain gameplay yang paling kuat setiap genre game.

\section{METODE}

Penelitian ini dilakukan dalam beberapa tahapan yang ditunjukkan dalam alur penelitian seperti yang ditunjukkan pada Gambar 1.

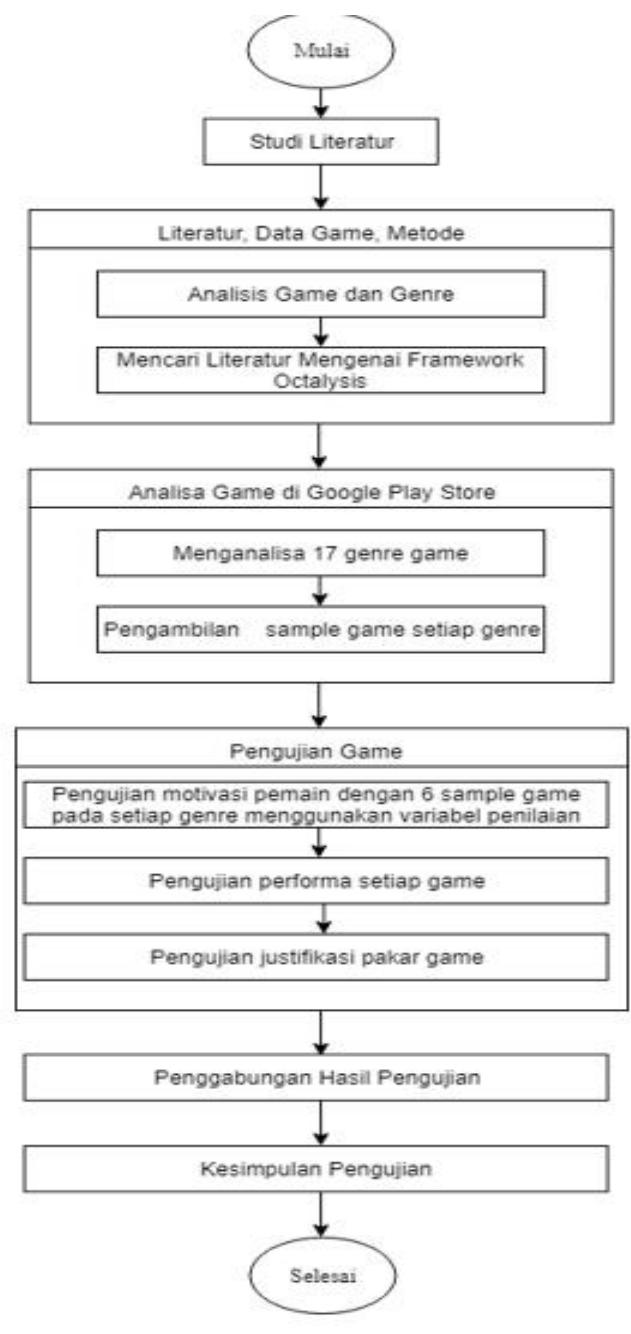

Gambar 1 Alur Penelitian

\section{Observational Studies}

Pada tahap ini dilakukan observasi pada penelitian terdahulu yang berhubungan dengan analisis pada game dengan melakukan studi literatur.

Penelitian yang berhubungan dengan human-computer interaction yang menggunakan aspek motivasi pemain dilakukan oleh Gustavo di dalam penelitian yang berjudul " $A$ Framework and Taxonomy of Video game Playing Preferences". Di dalam penelitian ini diungkapkan bahwa seorang pemain memiliki motivasi yang berbeda dalam memainkan sebuah produk game baik berdasarkan klasifikasi elemen game. Hasil dari penelitian ini berdasarkan hasil survey yang dilakukan pada 196 responden diungkapkan bahwa pemain game dengan jenis kelamin dan usia tertentu memiliki motivasi yang berbeda-beda dalam memainkan sebuah game, namun kolerasi antara elemen game dengan teknik permainan sangat tinggi sehingga pengelompokan sebuah jenis game dapat dikelompokkan berdasarkan usia dan jenis kelamin tertentu. (Tondello, Wehbe, Orji, Ribeiro, \& Nacke, 2017)

Pada penelitian yang dilakukan analisa game setiap genre di Google Play untuk mengetahui unsur terkuat 
setiap genre menggunakan parameter Tracy Fullerton berdasarkan elemen desain, sehingga setiap genre memiliki karakteristik elemen desain terkuat di dalam game. (Satria et al., 2018)

$$
\text { Penelitian pada game }
$$
menggunakan framework Octalysis dilakukan untuk menganalisis game Half Life dan Deus Ex: Fall Out dengan membandingkan review game menggunakan framework Octalysis dengan Metacritics. Hasil peneltian tersebut diungkapkan bahwa melakukan review game menggunakan framework Octalysis dengan Metacritics memiliki persamaan nilai motivasi pemain namun nilai obyektivitas tertinggi dimiliki oleh review yang dilakukan menggunakan framework Octalysis. (Salonen \& Mohammad, 2017)

Penelitian terhadap game dilakukan oleh Yu-kai Chou terhadap game Candy Crush Saga dan Farmville menggunakan framework Octalysis. Kedua game yang diteliti merupakan game yang dimainkan oleh jutaan pemain namun Candy Crush Saga yang memiliki jumlah pengunduh tertinggi dan memiliki kestabilan jumlah pemain dibandingkan dengan Farmville yang mengalami penurunan yang drastis pada tahun 2015. Di dalam penelitian ini diungkapkan bahwa Candy Crush Saga memiliki nilai Octalysis yang tinggi dan seimbang sedangkan Farmville memiliki nilai motivasi terendahnya adalah unsur Unrpedictability di mana game tersebut terlalu mudah diprediksi oleh pemain apa langkah selanjutnya dalam permainan ini. (Yu-Kai, 2016)

$$
\text { Penelitian menggunakan }
$$

framework Octalysis dilakukan untuk mengklasifikasi berbagai aplikasi Stress Management mHealth yang didistribusikan di Google Play Store menggunakan Octalysis. Analisis tersebut menghasilkan pernyataaan bahwa aplikasi Stress Management $m$ Health merupakan aplikasi yang tidak popular dikalangan pengguna smartphone namun aplikasi tersebut cukup banyak digunakan oleh pengguna yang memiliki kecenderungan emosional yang sulit diatur. Dengan memperhatikan tingkat emosional pengguna digabungkan dengan motivasi pengguna menggunakan metode Octalysis maka dapat dibuktikan bahwa aplikasi Stress Management mHealth yang diunduh terbanyak dan terpasang lama di dalam smartphone pengguna memiliki delapan inti motivasi yang terpenuhi dan keseimbangan Octalysis sedangkan aplikasi yang tidak dapat 
mencapai target delapan inti motivasi Octalysis maka aplikasi tersebut memiliki kecenderungan tidak bertahan lama. (Ewais \& Alluhaidan, 2015)

\section{Conceptual}

Tahap conceptual adalah tahap mencari bahan referensi dan teori-teori yang berhubungan dengan penelitian yang sedang dilakukan.

\section{a. Game}

Game dapat diartikan sebagai aktifitas terstruktur yang biasa dilakukan untuk bersenang-senang (playfull) (Schell, 2018). Aktivitas bermain yang dilakukan dalam kontek berpura-pura namun terlihat seperti realitas, yang mana pemainnya memiliki tujuan untuk mendapatkan satu kemenangan serta dilakukan sesuai dengan aturan permainan yang telah dibuat. (Ernest, 2010).

\section{Setiap game memiliki} karateristik dan cara bermain yang berbeda, perbedaan inilah yang membuat pengelompokan setiap game menjadi tipe-tipe yang hampir sama sehingga dibagi berdasarkan jenis (genre) permainannya action, advanture, arcade, board, card, casino, casual, educational, music, puzzle, racing, role playing, simulation, sports, strategy, trivia, dan word.

Penelitian ini akan mengambil tiga sampel game terpopular setiap genrenya sehingga didapatkan 41 game yang digunakan di dalam penelitian ini.

\section{b. Framework Octalysis}

Octalysis adalah kerangka desain gamification human-centric yang menjabarkan delapan drive inti untuk motivasi manusia. Framework ini bekerja berdasarkan pada premis bahwa sistem "berfokus pada fungsi" yang dirancang untuk menyelesaikan tugas secepat mungkin, mirip dengan proses pabrik dengan asumsi pekerja akan menyelesaikan tugas mereka tepat waktu karena memang menjadi bagian dari pekerjaannya. Namun, desain yang berfokus pada manusia diakui sangat berbeda dengan mesin dalam sistem memiliki perasaan, ketidaknyamanan, dan alasan mengapa manusia ingin atau tidak ingin melakukan hal-hal tertentu, oleh karena itu diperlukan optimalisasi perasaan, motivasi, dan keterlibatan manusia. Framework ini menjabarkan struktur untuk menganalisis kekuatan pendorong di belakang motivasi manusia. Proses ini digunakan untuk menyelesaikan tugas secara efisien 
melalui pengalaman interaktif. Pada intinya Octalysis digunakan untuk melakukan analisis seberapa besar keterlibatan manusia dengan melihat faktor motivasi yang dimilikinya Octalysis memiliki delapan drive inti antara lain: (Yu-Kai, 2016)

\section{1) Epic Meaning and Calling.}

Drive inti yang pertama ini digunakan untuk mengukur dan memahami seberapa besar tingkat kepercayaan seseorang dalam melakukan pekerjaan tersebut apakah yang dilakukannya berdasarkan keinginannya sendiri karena ada makna yang ingin dicapainya atau terpilih untuk melakukan pekerjaan itu.

\section{2) Development and Accomplisment}

Dorongan internal untuk membuat kemajuan, mengembangkan ketrampilan, mencapai penguasaan dan mengatasi tantangan. Persepsi mengenai tantangan itu penting, contohnya sebuah reward dalam bentuk lencana atau trofi tidak akan berarti tanpa adanya tantangan. Drive inti ini berfokus pada poin, lencana dan papan peringkat.

\section{3) Empowerment of Creatifity and Feedback \\ Pada drive ini pengguna} terlibat dalam proses di mana kreatifitas harus digunakan untuk menyelesaikan masalah baik dengan cara mencari cara baru atau mencoba kombinasi yang berbeda. Pengguna tidak hanya membutuhkan cara untuk mengekspresikan kreativitas mereka, tetapi juga perlu melihat hasil kreatifitas mereka dengan menerima umpan balik. Inilah sebabnya mengapa orang bermain Lego, Minecraft dan membuat seni secara intrinsik menyenangkan karena dari kreatifitas tersebut orang juga mendapatkan umpan balik baik berupa pujian.

\section{4) Ownership and Possession}

Drive ini mengacu pada pengguna yang merasa bahwa mereka memiliki atau dapat mengendalikan sesuatu. Ketika seseorang merasa memiliki sesuatu, mereka dengan sendirinya ingin meningkatkan dan memperbaiki apa yang mereka miliki. Sebagai contoh seseorang yang memiliki kekayaan dalam bentuk uang akan menggunakan kekayaan tersebut untuk meningkatkan jumlah uangnya dan mengendalikan uang tersebut untuk 
digunakan sesuai dengan kebutuhan dan keinginannya.

\section{5) Social Influence and Relatedness}

Pada drive ini, semua elemen sosial yang berhubungan dengan motivasi orang digabungkan menjadi satu yang di dalamnya terdapat bimbingan, persahabatan, penerimaan sosial, persaingan hingga iri hati. Ketika ada orang yang lain yang memiliki ketrampilan luar biasa maka ada dorongan untuk mencapai hal yang sama.

\section{6) Scarcity and Impatience}

Drive ini mendorong pengguna untuk mendapatkan dorongan untuk mencapai sesuatu yang langka, eksklusif atau susah untuk dicapai. Banyak permainan yang memiliki dinamika dengan janji dengan imingiming "Kembali dalam 2 jam untuk mendapatkan hadiah anda". Fakta ini membuktikan pada pengguna yang termotivasi untuk mendapatkan hadiah tersebut dengan cara terus-menerus memeriksa ketersediaan hadiah.

7) Unpredictability and Curiosity

Pada drive ini, ketidakpastian dan keingintahuan menjadi hal yang ditunggu oleh pengguna. Rasa penasaran karena tidak dapat menebak menjadi bagian penting dalam sebuah permainan yang memiliki tantangan.

\section{8) Loss and Avoidance}

Drive yang terakhir ini mengacu pada motivasi pengguna untuk menghindari sesuatu yang negatif. Contohnya adalah menghindari rintangan jurang agar tidak jatuh dan game over. Motivasi ini mengacu pada ketakutan dan kewaspadaan pengguna agar dapat melanjutkan permainan.

Di dalam Framework Octalysis dianalisa ke dalam sebuah grafik octagon seperti yang ditunjukkan pada Gambar 2.

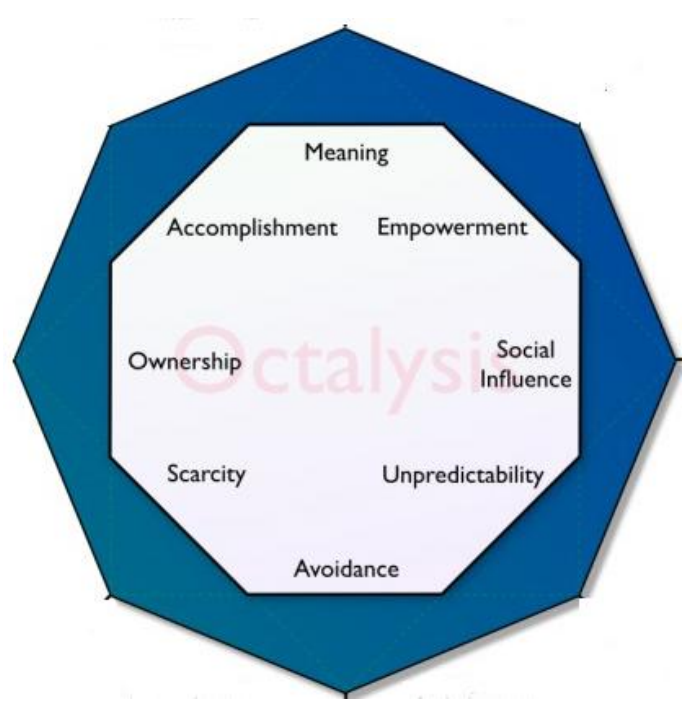

Gambar 2 Octagon Octalysis 


\section{c. Skala Likert}

Penelitian ini menggunakan selected sample dan menggunakan teknik pengambilan sampel untuk proses justifikasi pakar dengan pertimbangan tertentu yang disebut dengan teknik sampling purposive yang dapat memberikan salah satu acuan dalam pengambilan sampel yang dapat digunakan untuk penelitian. (Sugiyono, 2015).

Penilaian setiap sampel dengan menggunakan skala likert bernilai 5 untuk nilai yang dianggap sangat baik, 4 untuk nilai baik, 3 untuk nilai cukup,2 untuk nilai buruk, dan 1 untuk nilai sangat buruk seperti yang ditunjukkan pada Tabel 1 .

Tabel 1 Kriteria Penilaian Skala Likert

\begin{tabular}{|c|c|}
\hline Variabel & Keterangan \\
\hline 5 & Sangat Baik \\
\hline 4 & Baik \\
\hline 3 & Cukup \\
\hline 2 & Buruk \\
\hline 1 & Sangat Buruk \\
\hline
\end{tabular}

Setiap sample pada framework Octalysis akan dihitung secara kuantitatif di mana jumlah dari setiap unsur motivasi akan ditentukan menggunakan variabel pada Tabel 1 .

\section{Collecting}

Tahap ini adalah tahap pengumpulan data-data yang berhubungan dengan penelitian. Pada tahapan ini dilakukan dengan mengumpulkan data dari Google Playstore dengan menganalisa gamegame di 17 genre yang tersedia dan pengumpulan sampel game yang digunakan untuk penelitian ini menggunakan data yang diambil dari AndroidRank.Org tiga game terpopular setiap genre yang ditunjukkan pada Tabel 2.

Tabel 2 Sampel Game Dalam Penelitian

\begin{tabular}{|c|c|}
\hline Genre & Nama Game \\
\hline \multirow{3}{*}{ Action } & Garena Free Fire \\
\hline & Shadow Fight 2 \\
\hline & Mobile Legends: Bang Bang \\
\hline \multirow{3}{*}{ Adventures } & Pokemon Go \\
\hline & Roblox \\
\hline & Criminal Case \\
\hline \multirow{3}{*}{ Arcade } & Subway Surfers \\
\hline & Piano Tiles ${ }^{T M}$ \\
\hline & Geometry Dash Lite \\
\hline \multirow{3}{*}{ Board } & Ludo King ${ }^{T m}$ \\
\hline & 101 Yuzbir Okey Olu \\
\hline & 모두의마블 \\
\hline \multirow{3}{*}{ Card } & Uno ${ }^{T m} \&$ Friends \\
\hline & Yu-Gi-Oh! Duel Links \\
\hline & Heartstone \\
\hline \multirow{3}{*}{ Casino } & Zynga Poker - Texa Holdem \\
\hline & $\begin{array}{l}\text { Slotomania }{ }^{\mathrm{TM}} \text { Slots - Vegas } \\
\text { Casino Slot Games }\end{array}$ \\
\hline & Teen Patti by Octro \\
\hline \multirow{3}{*}{ Casual } & Candy Crush Saga \\
\hline & My Talking Tom \\
\hline & Pou \\
\hline
\end{tabular}




\begin{tabular}{|c|c|}
\hline Genre & Nama Game \\
\hline \multirow{3}{*}{ Educational } & Toca Kitchen 2 \\
\hline & $\begin{array}{l}\text { LEGO }{ }^{\circledR} \text { Juniors Create \& } \\
\text { Cruise }\end{array}$ \\
\hline & Cooking Mama: Let's cook! \\
\hline \multirow{3}{*}{ Music } & $\begin{array}{l}\text { Piano Free - KeyBoard with } \\
\text { Magic Tiles Music Games }\end{array}$ \\
\hline & Perfect Piano \\
\hline & Just Dance Now \\
\hline \multirow{3}{*}{ Puzzle } & Paperama \\
\hline & Fishdom \\
\hline & Cut the Rope FULL FREE \\
\hline \multirow{3}{*}{ Racing } & Hill Climb Racing \\
\hline & Asphalt 8: Airborne \\
\hline & Traffic Rider \\
\hline \multirow{3}{*}{$\begin{array}{l}\text { Role } \\
\text { Playing }\end{array}$} & Angry Birds Epic RPG \\
\hline & MARVEL Future Fight \\
\hline & Summoners War \\
\hline \multirow{3}{*}{ Simulations } & Dragon City \\
\hline & The Sims FreePlay \\
\hline & SimCity BuildIt \\
\hline \multirow{3}{*}{ Sports } & 8 Ball Pool \\
\hline & Dream League Soccer 2019 \\
\hline & Score! Hero \\
\hline \multirow{3}{*}{ Strategy } & Clash of Clans \\
\hline & Clash Royale \\
\hline & Boom Beach \\
\hline \multirow{3}{*}{ Trivia } & Trivia Crack \\
\hline & 94\% - Quiz, Trivia \& Logic \\
\hline & Logo Quiz \\
\hline \multirow{3}{*}{ Word } & Word Cookies ${ }^{\mathrm{TM}}$ \\
\hline & Words With Friends Classic \\
\hline & 4 Pics 1 Word \\
\hline
\end{tabular}

\section{Testing}

Pada tahap ini dilakukan pengujian pada game-game yang telah dipilih sebagai sampel penelitian menggunakan framework Octalysis. Pengujian dilakukan dengan cara memainkan langsung setiap game dengan melakukan pengujian struktur motivasi pemain dari game yang nantinya akan dilakukan penilaian pada struktur yang diuji.

Pengujian dilakukan terhadap setiap game dengan melakukan perekapan pada Tabel 3 di mana setiap parameter diujikan dengan menggunakan penilaian skala likert yang dikategorikan sesuai dengan kategori yang diujikan menggunakan framework Octalysis. Untuk menguji setiap genre maka peneliti akan membuat tabel yang mempermudah dalam mempelajari pengujian.

Tabel 3 Pengujian Game Candy Crush

\section{Saga}

\begin{tabular}{|c|c|c|c|c|c|c|}
\hline \multirow{2}{*}{ NO } & \multirow{2}{*}{$\begin{array}{c}\text { Deskripsi } \\
\text { Pertanyaan }\end{array}$} & \multicolumn{5}{|c|}{ SKOR } \\
\hline & & 5 & 4 & 3 & 2 & 1 \\
\hline \multicolumn{7}{|c|}{ Epic Meaning and Calling } \\
\hline 1 & $\begin{array}{l}\text { Opening game / Home } \\
\text { menu sangat mudah } \\
\text { untuk diingat meski baru } \\
\text { pertama kali bermain }\end{array}$ & & & & & \\
\hline 2 & $\begin{array}{l}\text { Opening game } \\
\text { memberikan informasi } \\
\text { mengenai game objective }\end{array}$ & & & & & \\
\hline \multicolumn{7}{|c|}{ Development and Accomplisment } \\
\hline 3 & $\begin{array}{l}\text { Game membuat pemain } \\
\text { mengejar reward berupa } \\
\text { trofi ataupun highscore } \\
\text { (Score Board) }\end{array}$ & & & & & \\
\hline 4 & $\begin{array}{l}\text { Game memiliki } \\
\text { tantangan yang semakin } \\
\text { sulit mengikuti } \\
\text { peningkatan level game }\end{array}$ & & & & & \\
\hline
\end{tabular}




\begin{tabular}{|c|c|c|c|c|c|c|}
\hline \multirow{2}{*}{$\begin{array}{l}\mathrm{N} \\
\mathrm{O}\end{array}$} & \multirow{2}{*}{$\begin{array}{l}\text { Deskripsi } \\
\text { Pertanyaan }\end{array}$} & \multicolumn{5}{|c|}{ SKOR } \\
\hline & & 5 & 4 & 3 & 2 & 1 \\
\hline \multicolumn{7}{|c|}{ Empowerment of Creativity and Feedback } \\
\hline 5 & $\begin{array}{l}\text { Terdapat teknik sesuai } \\
\text { dengan kreativitas } \\
\text { pemain untuk } \\
\text { menyelesaikan sebuah } \\
\text { misi }\end{array}$ & & & & & \\
\hline 6 & $\begin{array}{l}\text { Terdapat } \\
\text { rating/nilai/bintang/pujia } \\
\text { n jika anda } \\
\text { menyelesaikan sebuah } \\
\text { misi }\end{array}$ & & & & & \\
\hline \multicolumn{7}{|c|}{ Ownership and Possesion } \\
\hline 7 & $\begin{array}{l}\text { Game memiliki } \\
\text { tools/game money khusus } \\
\text { yang disimpan dan } \\
\text { digunakan sewaktu- } \\
\text { waktu untuk } \\
\text { menyelesaikan misi }\end{array}$ & & & & & \\
\hline 8 & $\begin{array}{l}\text { Adanya motivasi untuk } \\
\text { mendapatkan tools/game } \\
\text { money untuk } \\
\text { menyelesaikan suatu misi }\end{array}$ & & & & & \\
\hline \multicolumn{7}{|c|}{ Social Influence and Relatedness } \\
\hline 9 & $\begin{array}{l}\text { Terdapat button/integrasi } \\
\text { sosial media pada game } \\
\text { yang berguna untuk } \\
\text { menyimpan progres } \\
\text { game dan menemukan } \\
\text { teman yang memainkan } \\
\text { game yang sama. }\end{array}$ & & & & & \\
\hline 10 & $\begin{array}{l}\text { Integrasi sosial media } \\
\text { dapat menunjukkan } \\
\text { persaingan antar pemain }\end{array}$ & & & & & \\
\hline \multicolumn{7}{|c|}{ Scarcity and Impatience } \\
\hline 11 & $\begin{array}{l}\text { Game memiliki tools } \\
\text { yang langka/eksklusif } \\
\text { dan hanya di dapatkan } \\
\text { dalam event tertentu }\end{array}$ & & & & & \\
\hline 12 & $\begin{array}{l}\text { Untuk mendapatkan } \\
\text { reward atau tools } \\
\text { dibutuhkan waktu yang } \\
\text { cepat ( contoh :kembali } \\
\text { dalam } 3 \text { menit) } \\
\end{array}$ & & & & & \\
\hline \multicolumn{7}{|c|}{ Unpredictability and Curiosity } \\
\hline 13 & $\begin{array}{l}\text { Game memiliki } \\
\text { tantangan yang tidak } \\
\text { dapat ditebak/diprediksi } \\
\text { pada level atau misi } \\
\text { selanjutnya }\end{array}$ & & & & & \\
\hline 14 & $\begin{array}{l}\text { Game memunculkan rasa } \\
\text { penasaran "tantangan apa } \\
\text { yang akan didapatkan } \\
\text { pada level/misi } \\
\text { selanjutnya. }\end{array}$ & & & & & \\
\hline
\end{tabular}

\begin{tabular}{|c|c|c|c|c|c|c|}
\hline \multirow{2}{*}{ NO } & \multirow{2}{*}{$\begin{array}{c}\text { Deskripsi } \\
\text { Pertanyaan }\end{array}$} & \multicolumn{5}{|c|}{ SKOR } \\
\hline & & 5 & 4 & 3 & 2 & 1 \\
\hline \multicolumn{6}{|c|}{ Loss and Avoidance } & \\
\hline 15 & $\begin{array}{l}\text { Permainan membuat } \\
\text { anda menghindari } \\
\text { kesalahan yang membuat } \\
\text { anda kalah }\end{array}$ & & & & & \\
\hline 16 & $\begin{array}{l}\text { Terdapat rasa kecewa } \\
\text { jika anda tidak dapat } \\
\text { menyelesaikan suatu } \\
\text { level/misi }\end{array}$ & & & & & \\
\hline
\end{tabular}

Setiap genre diuji sebanyak tiga game dengan kriteria game terpopular setiap genre sehingga. Nilai setiap kategori dilakukan penjumlahan dan penghitungan rata-rata.

\section{NIlai Per Octalysis Genre Game1 + Game2 + Game3 $=$ 3}

(1)

Framework Octalysis tidak mengenal nilai angka dibelakang koma sehingga nilai rata-rata di atas 0,5 dibulatkan 1 nilai ke atas.

Hasil pengujian ketiga game tersebut menghasilkan seperti yang ditunjukkan pada Tabel 4.

Tabel 4 Penggabungan Pengujian Skala

Likert Pada Genre Game Casual

\begin{tabular}{|c|c|c|c|c|c|c|}
\hline \multirow[t]{2}{*}{ No } & \multirow[t]{2}{*}{$\begin{array}{c}\text { Framework } \\
\text { Octalysis }\end{array}$} & \multicolumn{3}{|c|}{ Game } & \multirow[t]{2}{*}{$\begin{array}{l}\text { Rata- } \\
\text { Rata }\end{array}$} & \multirow[t]{2}{*}{$\begin{array}{c}\text { Bul } \\
\text { at }\end{array}$} \\
\hline & & 1 & 2 & 3 & & \\
\hline 1 & $\begin{array}{l}\text { Epic Meaning } \\
\text { and Calling }\end{array}$ & 5 & 6 & 5 & 5,33 & 5 \\
\hline 2 & $\begin{array}{l}\text { Developmenta } \\
\text { and } \\
\text { Accomplisme } \\
\text { nt }\end{array}$ & 8 & 7 & 5 & 6,67 & 7 \\
\hline
\end{tabular}




\begin{tabular}{|c|l|c|c|c|c|c|}
\hline No & \multicolumn{1}{|c|}{$\begin{array}{c}\text { Framework } \\
\text { Octalysis }\end{array}$} & \multicolumn{3}{|c|}{ Game } & \multicolumn{1}{|c|}{$\begin{array}{c}\text { Rata- } \\
\text { Rata }\end{array}$} & $\begin{array}{c}\text { Bul } \\
\text { at }\end{array}$ \\
\hline 3 & $\begin{array}{l}\text { Empowerment } \\
\text { of Creativity } \\
\text { and Feedback }\end{array}$ & 9 & 7 & 6 & 7,33 & 7 \\
\hline 4 & $\begin{array}{l}\text { Ownership } \\
\text { and Possesion }\end{array}$ & 7 & 8 & 6 & 7 & 7 \\
\hline 5 & $\begin{array}{l}\text { Social } \\
\text { Influence and } \\
\text { Relatedness }\end{array}$ & 7 & 6 & 8 & 7 & 7 \\
\hline 6 & $\begin{array}{l}\text { Scarcity and } \\
\text { Impatience }\end{array}$ & 6 & 8 & 5 & 6,33 & 6 \\
\hline 7 & $\begin{array}{l}\text { Unpredictabili } \\
\text { ty and } \\
\text { Curiosity }\end{array}$ & 9 & 7 & 6 & 7,33 & 7 \\
\hline 8 & $\begin{array}{l}\text { Loss and } \\
\text { Avoidance }\end{array}$ & 9 & 8 & 7 & 8 & 8 \\
\hline
\end{tabular}

Gambar 3 Input Octalysis Tools

Hasil dari input pada Octalysis Tools menghasilkan octagon seperti yang ditunjukkan pada Gambar 4 di mana genre game casual memiliki keseimbangan motivasi pemain berdasarkan framework Octalysis.

\section{Hasil pembulatan rata-rata} tersebut dilakukan input pada Octalysis Tools seperti yang ditunjukkan pada Gambar 3.
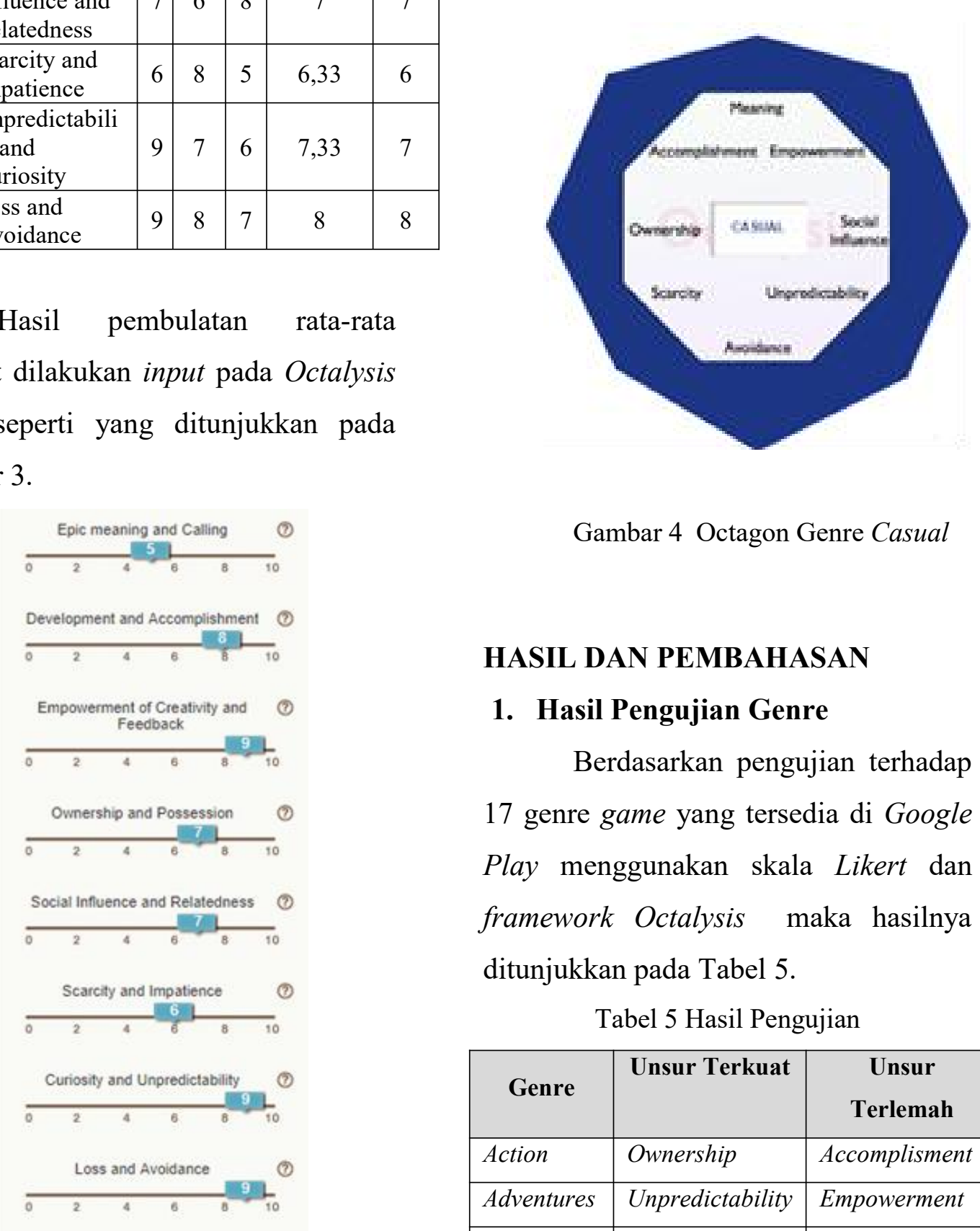

Gambar 4 Octagon Genre Casual

\section{HASIL DAN PEMBAHASAN}

\section{Hasil Pengujian Genre}

Berdasarkan pengujian terhadap 17 genre game yang tersedia di Google Play menggunakan skala Likert dan framework Octalysis maka hasilnya ditunjukkan pada Tabel 5.

Tabel 5 Hasil Pengujian

\begin{tabular}{|l|l|l|}
\hline \multicolumn{1}{|c|}{ Genre } & Unsur Terkuat & $\begin{array}{c}\text { Unsur } \\
\text { Terlemah }\end{array}$ \\
\hline Action & Ownership & Accomplisment \\
\hline Adventures & Unpredictability & Empowerment \\
\hline Arcade & Loss/Avoidance & Social Influence \\
\hline Board & Meaning & Empowerment \\
\hline
\end{tabular}




\begin{tabular}{|l|l|l|}
\hline Card & Empowerment & Accomplisment \\
\hline Casino & Ownership & Unpredictability \\
\hline
\end{tabular}

\begin{tabular}{|l|l|l|}
\hline \multicolumn{1}{|c|}{ Genre } & Unsur Terkuat & \multicolumn{1}{|c|}{$\begin{array}{c}\text { Unsur } \\
\text { Terlemah }\end{array}$} \\
\hline Casual & Balance & Balance \\
\hline Educational & Meaning & Accomplisment \\
\hline Music & Avoidance & Accomplisment \\
\hline Puzzle & Accomplisment & Meaning \\
\hline Racing & Meaning & Ownership \\
\hline $\begin{array}{l}\text { Role } \\
\text { Playing }\end{array}$ & Accomplisment & Ownership \\
\hline Simulation & Ownership & Meaning \\
\hline Sports & Accomplisment & Empowerment \\
\hline Strategy & Empowerment & Scarcity \\
\hline Trivia & Unpredictability & Accomplisment \\
\hline Word & Meaning & Unpredictability \\
\hline
\end{tabular}

\section{Uji Kelayakan Proses Pengujian}

Uji kelayakan dilakukan untuk mengetahui hasil dari pengujian berdasarkan Tabel 5. Dengan menggunakan selected sample dengan pertimbangan tertentu menggunakan teknik sampling purposive. Pengujian dilakukan menggunakan enam sampel yang memiliki kriteria dan pengaruh terhadap dunia game antara lain Pengembang game, desainer game, dan pakar game yang sudah berkompeten di bidangnya masing-masing. Hasil uji kelayakan yang dilakukan oleh pengembang game ditunjukkan pada Tabel 6.

Tabel 6 Uji Kelayakan Pengembang

\begin{tabular}{|c|c|c|c|}
\hline $\begin{array}{c}\text { No } \\
\text { Pertanyaan }\end{array}$ & $\begin{array}{c}\text { Pengembang } \\
\text { Pengembang }\end{array}$ & Total \\
\hline 1 & 5 & 4 & 9 \\
\hline 2 & 4 & 5 & 9 \\
\hline 3 & 4 & 4 & 8 \\
\hline 4 & 3 & 4 & 7 \\
\hline 5 & 5 & 3 & 8 \\
\hline 6 & 4 & 5 & 9 \\
\hline 7 & 4 & 4 & 8 \\
\hline 8 & 5 & 4 & 9 \\
\hline 9 & 5 & 3 & 8 \\
\hline 10 & 4 & 4 & 8 \\
\hline 11 & 4 & 4 & 8 \\
\hline 12 & 4 & 5 & 9 \\
\hline 13 & 4 & 4 & 8 \\
\hline 14 & 5 & 5 & 10 \\
\hline 15 & 3 & 4 & 7 \\
\hline 16 & 4 & 3 & 7 \\
\hline
\end{tabular}

Hasil uji kelayakan yang dilakukan oleh desain game ditunjukkan pada Tabel 7.

Tabel 7 Uji Kelayakan Desainer

\begin{tabular}{|c|c|c|c|}
\hline $\begin{array}{c}\text { No } \\
\text { Pertanyaan }\end{array}$ & $\begin{array}{c}\text { Desainer } \\
\mathbf{1}\end{array}$ & $\begin{array}{c}\text { Desainer } \\
\text { II }\end{array}$ & Total \\
\hline 1 & 4 & 4 & 8 \\
\hline 2 & 4 & 4 & 8 \\
\hline 3 & 4 & 5 & 9 \\
\hline 4 & 5 & 3 & 7 \\
\hline 5 & 4 & 4 & 8 \\
\hline 6 & 3 & 5 & 8 \\
\hline 7 & 3 & 4 & 7 \\
\hline 8 & 4 & 3 & 7 \\
\hline 9 & 4 & 5 & 9 \\
\hline 10 & 4 & 4 & 8 \\
\hline 11 & 5 & 3 & 8 \\
\hline 12 & 4 & 5 & 9 \\
\hline 13 & 4 & 4 & 8 \\
\hline 14 & 5 & 3 & 8 \\
\hline 15 & 4 & 5 & 9 \\
\hline
\end{tabular}


Hasil uji kelayakan yang dilakukan oleh pakar game ditunjukkan pada Tabel 8 .

Tabel 8 Uji Kelayakan Pakar

\begin{tabular}{|c|c|c|c|}
\hline $\begin{array}{c}\text { No } \\
\text { Pertanyaan }\end{array}$ & $\begin{array}{c}\text { Pakar } \\
\text { I }\end{array}$ & $\begin{array}{c}\text { Pakar } \\
\text { II }\end{array}$ & \\
\hline 1 & 5 & 4 & 9 \\
\hline 2 & 4 & 4 & 8 \\
\hline 3 & 5 & 5 & 10 \\
\hline 4 & 5 & 3 & 8 \\
\hline 5 & 4 & 4 & 8 \\
\hline 6 & 3 & 5 & 8 \\
\hline 7 & 5 & 4 & 9 \\
\hline 8 & 4 & 5 & 9 \\
\hline 9 & 5 & 5 & 10 \\
\hline 10 & 4 & 4 & 8 \\
\hline 11 & 5 & 3 & 8 \\
\hline 12 & 4 & 5 & 9 \\
\hline 13 & 4 & 4 & 8 \\
\hline 14 & 5 & 5 & 10 \\
\hline 15 & 4 & 5 & 9 \\
\hline 16 & 4 & 4 & 8 \\
\hline
\end{tabular}

Hasil uji kelayakan dari Tabel 6

Tabel 7 dan Tabel 8 direkap di dalam Tabel 9.

Tabel 9 Jumlah dan Rata-Rata Uji Kelayakan

\begin{tabular}{|c|c|c|c|c|}
\hline $\begin{array}{c}\text { No } \\
\text { Pertany } \\
\text { aan }\end{array}$ & $\begin{array}{c}\text { Total Uji } \\
\text { Pengemb } \\
\text { ang }\end{array}$ & $\begin{array}{c}\text { Total Uji } \\
\text { Desainer }\end{array}$ & $\begin{array}{c}\text { Total } \\
\text { Uji } \\
\text { Pakar }\end{array}$ & Total \\
\hline 1 & 9 & 8 & 9 & 26 \\
\hline 2 & 9 & 8 & 8 & 25 \\
\hline 3 & 8 & 9 & 10 & 27 \\
\hline 4 & 7 & 7 & 8 & 22 \\
\hline 5 & 8 & 8 & 8 & 24 \\
\hline 6 & 9 & 8 & 8 & 25 \\
\hline 7 & 8 & 7 & 9 & 24 \\
\hline 8 & 9 & 7 & 9 & 25 \\
\hline
\end{tabular}

\begin{tabular}{|c|c|c|c|c|}
\hline 9 & 8 & 9 & 10 & 27 \\
\hline 10 & 8 & 8 & 8 & 24 \\
\hline 11 & 8 & 8 & 8 & 24 \\
\hline 12 & 8 & 9 & 9 & 26 \\
\hline $\begin{array}{c}\text { No } \\
\text { Pertany } \\
\text { aan }\end{array}$ & $\begin{array}{c}\text { Total Uji } \\
\text { Pengemb } \\
\text { ang }\end{array}$ & $\begin{array}{c}\text { Total Uji } \\
\text { Desainer }\end{array}$ & $\begin{array}{c}\text { Total } \\
\text { Uji } \\
\text { Pakar }\end{array}$ & Total \\
\hline 13 & 8 & 8 & 8 & 24 \\
\hline 14 & 10 & 8 & 10 & 28 \\
\hline 15 & 7 & 9 & 9 & 25 \\
\hline 16 & 7 & 8 & 8 & 23 \\
\hline
\end{tabular}

Tahapan pengujian berikutnya adalah menelaah setiap pertanyaan yang sesuai dengan kategorial framework Octalysis, sebagai contoh pertanyaan nomor 1 dan 2 mewakili pertanyaan mengenai Epic Meaning and Calling dan seterusnya.

Perekapan hasil nilai jawaban pada Tabel 8 kemudian dilakukan proses penghitungan prosentase dengan rumus sebagai berikut :

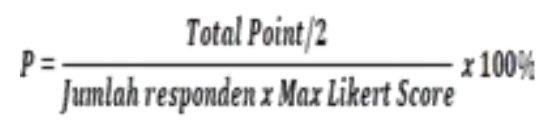

Sehingga hasil prosentase tersebut ditunjukkan pada Tabel 10.

Tabel 10 Prosentase Uji Kelayakan

\begin{tabular}{|c|l|c|c|}
\hline $\begin{array}{c}\text { No } \\
\text { Pertanyaan }\end{array}$ & \multicolumn{1}{|c|}{$\begin{array}{c}\text { Framework } \\
\text { Octalysis }\end{array}$} & Total & Prosentase \\
\hline $1-2$ & $\begin{array}{l}\text { Epic Meaning and } \\
\text { Calling }\end{array}$ & 51 & $85 \%$ \\
\hline $3-4$ & $\begin{array}{l}\text { Development and } \\
\text { Accomplisment }\end{array}$ & 49 & $81.67 \%$ \\
\hline $5-6$ & $\begin{array}{l}\text { Empowerment of } \\
\text { Creativity and } \\
\text { Feedback }\end{array}$ & 49 & $81.67 \%$ \\
\hline $7-8$ & $\begin{array}{l}\text { Ownership and } \\
\text { Possesion }\end{array}$ & 49 & $81.67 \%$ \\
\hline $9-10$ & $\begin{array}{l}\text { Social Influence } \\
\text { and Relatedness }\end{array}$ & 51 & $85 \%$ \\
\hline $11-12$ & Scarcity and & 50 & $83.3 \%$ \\
\hline
\end{tabular}




\begin{tabular}{|c|l|c|c|}
\hline & Impatience & & \\
\hline $13-14$ & $\begin{array}{l}\text { Unpredictability } \\
\text { and Curiosity }\end{array}$ & 52 & $86.67 \%$ \\
\hline $15-16$ & $\begin{array}{l}\text { Loss and } \\
\text { Avoidance }\end{array}$ & 48 & $80 \%$ \\
\hline
\end{tabular}

Dari delapan kategori yang masing-masing memiliki dua pertanyaan yang mewakili unsur motivasi pemain menggunakan framework Octalysis dengan tabel interval uji kelayakan ditunjukkan pada Tabel 11.

Tabel 11 Prosentase Uji Kelayakan

\begin{tabular}{|c|c|c|}
\hline $\begin{array}{c}\text { Interval } \\
\text { Uji } \\
\text { Kelayakan }\end{array}$ & Kriteria & $\begin{array}{c}\text { Jumlah } \\
\text { Unsur } \\
\text { Motivasi }\end{array}$ \\
\hline $0 \%-20 \%$ & Sangat Tidak Setuju & 0 \\
\hline $21 \%-40 \%$ & Tidak Setuju & 0 \\
\hline $41 \%-60 \%$ & Cukup Setuju & 0 \\
\hline $61 \%-80 \%$ & Setuju & 1 \\
\hline $81 \%-100 \%$ & Sangat Setuju & 7 \\
\hline
\end{tabular}

\section{Hasil Pengujian Keseluruhan}

Hasil dari pengujian di dalam penelitian ini terbagi menjadi dua yang pertama pengujian menggunakan framework Octalysis dan pengujian berikutnya merupakan justifikasi dari enam pakar yang hasilnya ditunjukkan pada Tabel 10 yang menunjukkan tidak ditemukannya motivasi Octalysis yang memiliki inteinsitas 0\%-20\%, 21\%-40\%, dan $41-60 \%$, terdapat 1 unsur motivasi yang memiliki intensitas $61 \%-80 \%$ dengan kriteria setuju dan 7 unsur motivasi yang memiliki intensitas $81 \%$ 100\% dengan kriteria sangat setuju.

\section{Kesimpulan}

Berdasarkan hasil analisis dan tahapan menggunakan framework Octalysis dan pengujian responden sehingga dapat disimpulkan sebagai berikut :

a. Dalam pengujian terhadap 17 genre yang terdapat pada Google Play menggunakan framework Octalysis ditemukan bahwa genre game casual memiliki keseimbangan nilai motivasi yang seimbang dengan delapan drive inti sehingga segala unsur desain dan gameplay wajib dipertimbangkan sesuai dengan delapan drive inti Octalysis.

b. Penelitian ini berhasil menentukan setiap nilai variabel motivasi menggunakan framework Octalysis dan menentukan unsur motivasi terkuat sehingga mempermudah responden untuk menganalisa setiap unsur di mana terdapat 3 unsur motivasi yang memiliki intensitas $61 \%-80 \%$ dengan kriteria setuju dan 5 unsur motivasi yang memiliki intensitas $81 \%-100 \%$ dengan kriteria sangat setuju. 
c. Framework Octalysis dapat diterapkan untuk menentukan unsur motivasi terkuat untuk menentukan perbedaan setiap genre game yang terdapat pada Google Play dengan nilai kelayakan yang diberikan responden sebesar 84\% sehingga dapat disimpulkan bahwa layak untuk diterapkan.

\section{Saran}

Menyimpulkan hasil masukkan dan saran dari responden dan peneliti dilakukan pengujian dengan responden dari pemain game untuk mendapatkan justifikasi hasil pengujian yang nilainya akan berbeda. Selain itu diperlukannya pengujian setiap genre dengan jumlah sampling game yang lebih banyak untuk mendapatkan tingkat keakuratan yang jauh lebih tinggi dan diperlukan pembaharuan penelitian untuk model pengujian terhadap platform selain Android.

\section{DAFTAR PUSTAKA}

Ernest, A., 2010. Fundamental Of Game Design Second Edition. Berkeley: New Riders Games.

Ewais, S., \& Alluhaidan, A., 2015, Classification of stress management mHealth apps based on Octalysis framework. 2015

Americas Conference on Information Systems, AMCIS 2015, (March), 1-8.

Salonen, A., \& Mohammad, A., 2017, Practicing Octalysis The comparison of an Octalysis analysis versus Metacritic's reviews. Retrieved from http://www.divaportal.org/smash/get/diva2:110844 1/FULLTEXT01.pdf

Satria, D. A., Utami, E., \& Luthfi, E. T, 2018, Analisis Perbedaan Genre Game Pada Google Playstore Menggunakan Parameter Tracy Fullerton. Jurnal Ilmiah Bidang Teknologi Angkasa, 10, 10.

Schell, J., 2018, Art Of Games Design. Elsevier Inc.

Statista., 2017, Global market share held by smartphone operating systems from 2009 to 2017. Retrieved October 20, 2018, from https://www.statista.com/statistics/ 263453/global-market-share-heldby-smartphone-operating-systems/

Sugiyono., 2015, Metode Penelitian Manajemen. Bandung: Alfabeta.

Tondello, G. F., Wehbe, R. R., Orji, R., Ribeiro, G., \& Nacke, L. E., 2017, A Framework and Taxonomy of Videogame Playing Preferences. Proceedings of the Annual Symposium on Computer-Human InterAction in Play - CHI PLAY '17, 329-340. https://doi.org/10.1145/3116595.31 16629

Yu-Kai, C., 2016, Actionable 
Gamification. Antimicrobial agents

and chemotherapy (Books).

California: Octalysis Media.

https://doi.org/10.1128/AAC.0372

8-14 